\title{
PENGARUH PEMBERIAN GEL KOMBINASI EKSTRAK GETAH PEPAYA (Carica papaya L) DAN EKSTRAK DAGING LIDAH BUAYA (Aloe vera) TERHADAP PROSES PENYEMBUHAN ULKUS TRAUMATIKUS PADA MALE WISTAR RATS YANG MENDERITA DIABETES MELITUS
}

Umi Kulsum* ${ }^{\star}$ Ratnawati Hendari**, Siti Chumaeroh ${ }^{* *}$

\begin{tabular}{c}
\hline Keywords: \\
Aloevera, Papaya Latex \\
Extract, Traumatics \\
Ulcers \\
\hline
\end{tabular}

\section{ABSTRACT}

Introduction: Research on the use of papaya and aloevera sap on wound healing each been done, but effects the combination of the two extracts on wound healing in diabetes mellitus condition has not been done.

Purpose: This study aims to determine the effect of a gel combination of papaya latex and aloevera flesh extracts on the traumatics ulcer healing process in diabetic rats.

Methods: True experimental laboratory research with the post-test-only control group design that performed on 28 male wistar rats which were divided into four groups: DM and non-DM rat that treatment with povidone iodine and gel combination of papaya latex and aloevera flesh extract. The treatment was done for 7 days with smearing that was given $2 x$ /day. Traumatics ulcer healing seen from the number of fibroblasts that then were analyzed by One Way Anova and post hoc LSD test.

Results: The results showed the number of fibroblasts in DM and non-DM rat with povidone iodine were 44.6 and 42.73 ; in the DM and non-DM rat with a gel combination of papaya latex and aloe vera flesh extracts were 61.10 and 77.03. One Way Anova test resulted $p$-value $=0.000$, it was mean that there were at least a significant difference on the number of fibroblasts in the two groups. Differences of the number fibroblasts was shown in all groups, except in the group DM and non-DM rats with povidone iodine $(p=0.764)$.

Conclusion: Conclusion of the study was the provision of a gel combination of papaya latex and aloevera flesh extracts effect on the traumatics ulcer healing process in diabetic rats.

\section{PENDAHULUAN}

Diabetes melitus (DM) atau kencing manis adalah penyakit menahun yang ditandai dengan meningkatnya kadar glukosa darah dan gangguan metabolisme karbohidrat, lemak, dan protein yang disebabkan oleh kekurangan hormon insulin. Diabetes melitus merupakan suatu kelompok penyakit metabolik dengan karakteristik hiperglikemia yang terjadi karena kelainan sekresi insulin, kerja insulin, atau kedua - duanya yang berhubungan dengan kerusakan jangka panjang, disfungsi, atau kegagalan beberapa organ tubuh ${ }^{1,2}$.

Diabetes melitus mempunyai komplikasi yaitu mikroangiopati, nefropati, neuropati, penyakit makro vaskuler dan penyembuhan luka yang lambat ${ }^{3}$. Luka adalah hilang atau rusaknya sebagian jaringan tubuh ${ }^{4}$. Salah satu luka yang terjadi di rongga mulut adalah ulkus traumatikus. Ulkus traumatikus bisa disebabkan oleh bahan-bahan kimia, panas, listrik, atau gaya mekanik yang melukai ${ }^{5}$, serta penggunaan obat-obat kedokteran gigi yang bersifat kaustik seperti obat kumur beralkohol tinggi, eugenol dan hidrogen peroksida ${ }^{6}$.

Penyembuhan pada ulkus sama dengan penyembuhan luka pada umumnya yaitu melewati fase inflamasi, fase proliferasi dan fase maturasi ${ }^{7}$. Salah satu obat yang sering digunakan oleh masyarakat untuk penyembuhan luka adalah povidon iodin. Povidon iodin memiliki efek antimikroba, menciptakan lingkungan lembab dan dapat

*Program Pendidikan Dokter Gigi Fakultas Kedokteran Gigi Unissula Semarang, ** Staff Pengajar Fakultas Kedokteran Gigi Universitas Islam Sultan Agung Semarang

Korespondensi: umiumiumi.halc@gmail.com 
menginduksi angiogenesis. Obat ini juga dapat mencegah inflamasi. Namun penggunaan povidoniodin memiliki efek samping yaitu iritasi lokal dan dapat menimbulkan alergi serta meninggalkan residu. Dikatakan pula penggunaan povidon iodin memiliki efek menghambat pertumbuhan fibroblas pada percobaan kultur sel secara in vitro 8.9 .

Saat ini banyak penelitian menggunakan tanaman obat karena tanaman obat lebih sehat dibanding produk sintetis ${ }^{10}$. dan juga banyak tersedia di alam.Salah satu bahan tradisional yang bisa dipakai sebagai bahan alternatif pengobatan adalah papaya (Carica papaya L.). Menurut Donna yang dikutip dari Mayefis, kandungan papain dalam papaya sudah banyak dikembangkan. Papain dipercaya mampu melarutkan sel-sel mati yang melekat pada kulit ${ }^{11}$. Menurut Starley dkk dan Azarkan dkk selain papain, getah pepaya juga mengandung kimopapain, papaya peptidase, pectin D-galaktase, dan L-arabinose ${ }^{11}$. Papain dari getah pepaya menurut Starley dkk juga terbuki dapat digunakan sebagai antibakteri, menurut Gupta dkk juga bersifat antiinflamasi, serta mempercepat penyembuhan luka (Ayob; Mahmood dan Salmah; Hewitt dkk ${ }^{11}$.

Penelitian menggunakan getah pepaya pada 25 ekor mencit galur swiss betina dengan konsentrasi $25 \%, 50 \%, 100 \%$ telah dilakukan dan terbukti konsentrasi $100 \%$ yang paling efektif dalam membantu proses penyembuhan luka sayat ${ }^{12}$. Sebelumnya juga telah dilakukan penelitian kombinasi getah pepaya dan tanaman pegagan (Centella asiacita L.) dalam membantu proses penyembuhan luka bakar. Dan terbukti kombinasi ekstrak getah pepaya dan ekstrak pegagan memperlihatkan waktu penyembuhan lebih cepat dibandingkan bentuk tunggalnya masing-masing ${ }^{11}$.

Selain pepaya, lidah buaya (Aloe vera) telah lama diketahui sebagai tanaman penyembuh luka. Gel aloe vera memilki aktifitas sebagai antibakteri, antijamur, peningkat aliran darah ke daerah yang terluka dan penstimulasi fibroblas yang bertanggung jawab untuk penyembuhan luka ${ }^{13}$. Lidah buaya mengandung banyak zat-zat aktif antara lain glukomanan, lignin, vitamin A, vitamin $C$, enzim-enzim serta asam amino yang sangat penting untuk regenerasi sel-sel. Lidah buaya menstimulasi faktor pertumbuhan epidermis, meningkatkan fungsi fibroblas, dan pembentukan pembuluh darah baru sehingga mempercepat penyembuhan dan penutupan luka $^{14,15}$. Penelitian sebelumnya menggunakan lidah buaya pada 25 ekor tikus putih jantan dengan konsentrasi $25 \%, 50 \%, 75 \%, 100 \%$ dan konsentrasi $75 \%$ terbukti paling efektif dapat mempercepat penyembuhan radang mukosa mulut tikus yang diukur dari jumlah makrofag ${ }^{16}$.

\section{METODE PENELITIAN}

Penelitian laboratorium true experimental dengan rancangan the post test-only control group design yang dilakukan pada 28 ekor tikus male wistar. Tikus yang dipilih memiliki ciri-ciri: sehat, umur 2-3 bulan, dan berat 150200 gram. Tikus dibagi dalam empat kelompok terdiri dari Kelompok DM dan Non DM yang diberi povidon iodin, dan kelompok DM dan Non DM yang diberi gel kombinasi ekstrak getah pepaya $100 \%$ + gel ekstrak daging lidah buaya $100 \%$. Gel ekstrak getah pepaya dan daging lidah buaya dibuat dengan metode maserasi menggunakan pelarut etanol $96 \%$.

Tikus diadaptasi selama tujuh hari, dibagi menjadi dua kelompok masing-masing terdiri dari 14 ekor tikus untuk tikus DM dan 14 tikus non DM. Pada kelompok tikus DM hari pertama setelah adaptasi dipuasakan sedikitnya 8 jam untuk pengukuran kadar gula darah puasa kemudian dilanjutkan dengan induksi aloksan monohidrat dosis $110 \mathrm{mg} / \mathrm{kgBB}$. Tiga hari kemudian diperiksa kembali kadar gula darah puasanya untuk memastikan bahwa tikus mengalami diabetes bila kadar gula darah mencapai $200 \mathrm{mg} / \mathrm{dl}$ dalam dua hari berturutturut ${ }^{17}$. Semua tikus dianastesi dengan ketamin $\mathrm{HCl} 20-40 \mathrm{mg} / \mathrm{kg}$ berat badan secara injeksi intramuskular ${ }^{18}$. untuk kepentingan 
pembuatan lesi. Lesi dibuat dengan pemberian hidrogen peroksida $\left(\mathrm{H}_{2} \mathrm{O}_{2}\right) 30 \%$ menggunakan micro brush (diameter $2 \mathrm{~mm}$ ) pada bagian mukosa labial sehingga terjadi iritasi mukosa labial tikus. Setelah diberi perlukaan dibiarkan selama 24 jam agar terbentuk luka, kemudian dibagi menjadi empat kelompok perlakuan secara acak. Perlakuan dilakukan dalam $2 x$ sehari pada pagi dan sore selama 7 hari. Pengamatan jumlah fibroblas sebagai ukuran penyembuhan luka diperoleh dari preparat mikroskopis jaringan ulserasi mukosa Male wistar rats yang dibuat dengan pengecatan
Hematoxcylin-Eosin dan dilihat pada lima lapang pandang dengan menggunakan mikroskop elektrik dengan perbesaran 400x. Jumlah fibroblas yang selanjutnya dianalisis menggunakan uji One Way Anova dan Post Hoc LSD.

\section{HASIL PENELITIAN}

Rata-rata hasil perhitungan jumlah sel fibroblas pada masing-masing kelompok seperti terlihat pada tabel 1 .

Tabel 1. Data rata-rata jumlah sel fibroblas

\begin{tabular}{lcc}
\hline \multicolumn{1}{c}{ Kelompok } & \multicolumn{2}{c}{ Jumlah sel Fibroblas } \\
& Mean & Std. Deviasi \\
\hline - DM povidon iodin & 44.60 & 8.81 \\
- Non DM povidon iodin & 42.73 & 7.86 \\
- DM Gel kombinasi ekstrak & 61.10 & 4.71 \\
$\quad$ getah pepaya + lidah buaya & & 17.05 \\
- Non DM Gel kombinasi ekstrak & 77.03 & \\
\hline getah pepaya + lidah buaya & & \\
\hline
\end{tabular}

Tabel 2. Perbandingan jumlah sel fibroblas menggunakan uji Post Hoc LSD

\begin{tabular}{|c|c|c|c|c|}
\hline & $\begin{array}{l}\text { DM } \\
\text { Povidon } \\
\text { Iodin }\end{array}$ & $\begin{array}{l}\text { Non DM } \\
\text { Povidon } \\
\text { Iodin }\end{array}$ & $\begin{array}{c}\text { DM Gel } \\
\text { kombinasi ekstrak } \\
\text { getah pepaya }+ \\
\text { lidah buaya }\end{array}$ & $\begin{array}{c}\text { Non DM Gel } \\
\text { kombinasi ekstrak } \\
\text { getah pepaya }+ \\
\text { lidah buaya }\end{array}$ \\
\hline DM Povidon Iodin & & 0.764 & $0.012^{*}$ & $0.000^{*}$ \\
\hline $\begin{array}{l}\text { Non DM Povidon } \\
\text { Iodin }\end{array}$ & & & $0,007^{*}$ & $0,000^{*}$ \\
\hline $\begin{array}{c}\text { DM Gel kombinasi } \\
\text { ekstrak getah pepaya }+ \\
\text { lidah buaya }\end{array}$ & & & & $0,017^{*}$ \\
\hline $\begin{array}{c}\text { Non DM Gel } \\
\text { kombinasi ekstrak } \\
\text { getah pepaya + lidah } \\
\text { buava }\end{array}$ & & & & \\
\hline
\end{tabular}


Berdasarkan tabel 1, rata-rata jumlah sel fibroblas pada kelompok Non DM yang diberi povidon iodin sebesar 42.73 adalah terendah dibandingkan kelompok yang lain, adapun rata-rata tertinggi didapati pada kelompk Non DM yang diberi gel kombinasi ekstrak getah pepaya $100 \%$ dan ekstrak daging lidah buaya $100 \%$ yaitu sebesar 10.85 .

Uji One way Anova menghasilkan nilai $p$ value sebesar $0.000(<0.05)$ yang berarti bahwa ada perbedaan yang bermakna/ signifikan minimal antara dua pasangan kelompok. Pasangan kelompok mana saja yang berbeda diketahui dari hasil uji Post Hoc Test LSD seperti yang terlihat pada tabel 2.

Hasil post hoc test menunjukkan bahwa perbandingan antar kelompok terdapat perbedaan yang signifikan kecuali pada kelompok DM yang diberi povidon iodin dengan kelompok non DM yang diberi povidon iodin diperoleh bahwa tidak terdapat perbedaan yang signifikan.

\section{DISKUSI}

Perbedaan jumlah fibroblas antara kelompok Non DM yang diberi povidon iodin dengan kelompok Non DM yang diberi gel kombinasi ekstrak getah pepaya $100 \%$ dan ekstrak daging lidah buaya $100 \%$ membuktikan bahwa getah pepaya dan lidah buaya memiliki beberapa kandungan saponin, flavanoid dan vitamin $A$ dan $C$ yang memiliki aktifitas sebagai sebagai antibakteri, antiinflamasi dan peningkat aliran darah ke daerah yang terluka dan penstimulasi fibroblas yang bertanggung jawab untuk penyembuhan luka ${ }^{13}$. Sedangkan povidon iodin memiliki efek antimikroba, menciptakan lingkungan lembab dan dapat menginduksi angiogenesis. Obat ini juga dapat mencegah inflamasi. Namun penggunaan povidon iodin memiliki efek samping yaitu iritasi lokal dan dapat menimbulkan alergi serta meninggalkan residu. Dikatakan pula penggunaan povidon iodin memiliki efek menghambat pertumbuhan fibroblas ${ }^{8,9}$.
Perbedaan jumlah fibroblas pada kelompok DM yang diberi gel kombinasi ekstrak getah pepaya $100 \%$ dan ekstrak daging lidah buaya 100\% dengan kelompok Non DM yang diberi gel kombinasi ekstrak getah pepaya $100 \%$ dan ekstrak daging lidah buaya $100 \%$ terjadi karena pada penderita diabetes terjadi peningkatkan sitokin proinflamasi selama proses penyembuhan luka sehingga mengakibatkan memanjangnya fase inflamasi dan penyembuhan luka yang lama ${ }^{19}$.

Hasil penelitian ini dengan penelitian yang dilakukan oleh Gultom ${ }^{12}$, dimana peneliti menggunakan getah pepaya pada 25 ekor mencit galur swiss betina dengan konsentrasi $25 \%, 50 \%, 100 \%$ dan terbukti konsentrasi $100 \%$ yang paling efektif dalam membantu proses penyembuhan luka sayat. Pepaya mempunyai kandungan antara lain papain, saponin dan flavanoid. Papain yang merupakan salah satu agen enzymatic debridement dapat mencerna jaringan nekrotik karena mempunyai aktivitas katalitik dengan mencairkan eschar (keropeng yang dihasilkan luka bakar) sehingga memudahkan migrasi sel dari tepi luka ke daerah luka. Papain juga berguna dalam mengurangi infeksi bakteri, mengurangi eksudat dan meningkatkan pembentukan jaringan granulasi ${ }^{20}$.

Saponin mempunyai efek antibakteri, antivirus dan antiinflamasi.Saponin dapat mempercepat proses penyembuhan luka dengan cara meningkatkan faktor pertumbuhan endotel vaskuler dan interleukin (IL)-1 $\beta$ yang merupakan salah satu mediator inflamasi. Mediator inflamasi ini mampu menginduksi makrofag menuju daerah yang terluka dan mempercepat proses penyembuhan luka ${ }^{21}$. Lalu kandungan pepaya yang lain yaitu flavanoid. Flavonoid memiliki kemampuan imunomodulator yang dapat meningkatkan produksi IL-2 (interleukin 2). IL-2 merangsang proliferasi dan diferensiasi sel T. Kemudian sel T berdiferensiasi menjadi Th1 (T helper 1). Sel Th1 mensekresi berbagai macam produk antara lain IFN-y (interferon gamma) yang potensial mengaktivasi makrofag ${ }^{22}$. Makrofag 
yang aktif berfungsi untuk melakukan fagositosis, memproduksi sitokin, perbaikan jaringan (fibroblast stimulating factor, fibronectin, kolagenase), dan memproduksi hormon pertumbuhan (growth factor). Growth factor ini bertanggung jawab atas terjadinya inflamasi dan proses mitogen fibroblas yang penting dalam proses penyembuhan luka ${ }^{23}$.

Selain pepaya, lidah buaya (Aloe vera) telah lama diketahui sebagai tanaman penyembuh luka. Gel aloe vera memiliki aktifitas sebagai antibakteri, antijamur, peningkat aliran darah ke daerah yang terluka dan penstimulasi fibroblas yang bertanggung jawab untuk penyembuhan luka ${ }^{13}$. Lidah buaya mengandung banyak zat-zat aktif antara lain acemannan, lignin, vitamin $A$, vitamin $C$, enzim-enzim serta asam amino yang sangat penting untuk regenerasi sel-sel. Lidah buaya menstimulasi faktor pertumbuhan epidermis, meningkatkan fungsi fibroblas, dan pembentukan pembuluh darah baru sehingga mempercepat penyembuhan dan penutupan luka ${ }^{14,15}$.

Acemannan (acetyled mannan) merupakan polisakarida terbesar yang ada didalam daging lidah buaya. Acemannan berperan sebagai imunomdulator yang dapat menstimulasi makrofag, lomfosit, interleukin, sitokin dan TNF Acemannan juga berfungsi sebagai antiinflamasi, penyembuhan luka , antibakteri, antivirus dan anti jamur ${ }^{24}$. Selsel yang distimulasi oleh acemannan seperti makrofag dan limfosit akan menstimulasi TGF- $\beta$, PDGF, bFGF dan VEGF yang akan menginduksi migrasi dan proliferasi fibroblas ${ }^{25}$. Saponin dalam kandungan lidah buaya merupakan golongan steroid yang mempunyai efek antibakteri, antivirus dan antiinflamasi. Saponin dapat mempercepat proses penyembuhan luka dengan cara meningkatkan faktor pertumbuhan endotel vaskuler dan interleukin (IL)-1 $\beta$ yang merupakan salah satu mediator inflamasi. Mediator inflamasi ini mampu menginduksi makrofag menuju daerah yang terluka dan mempercepat proses penyembuhan luka ${ }^{21}$. Kandungan lain yang terdapat dalam lidah buaya adalah vitamin $\mathrm{A}$, B1, B2, B6, B12, C, E dan asam folat, yang berfungsi menjalankan fungsi tubuh secara normal dan sehat ${ }^{26}$.

Vitamin C juga berperan dalam diferensiasi sel, sintesis kolagen dan meningkatkan proliferasi fibroblas.Vitamin C juga dapat meningkatkan kekebalan tubuh. Kekebalan tubuh yang baik akan mempercepat proses proliferasi fibroblas ${ }^{27}$.

\section{KESIMPULAN}

Berdasarkan hasil pembahasan dapat ditarik kesimpulan sebagai berikut:

1. Rata-rata jumlah sel fibroblas pada tikus yang mendrita DM yang diberi Povidon lodin sebesar 44.60, pada tikus Non DM yang diberi Povidon lodin sebesar 42.73, pada tikus DM yang diberi kombinasi ekstrak getah pepaya $100 \%$ dan ekstrak daging lidah buaya $100 \%$ sebesar 61.10 , dan pada tikus Non DM yang diberi kombinasi ekstrak getah pepaya $100 \%$ dan ekstrak daging lidah buaya $100 \%$ sebesar 77.03 .

2. Ada pengaruh pemberian ektrak getah pepaya $100 \%$ dan ektrak daging lidah buaya $100 \%$ terhadap proses penyembuhan ulkus traumatikus tikus pada tikus yang menderita DM.

\section{DAFTAR PUSTAKA}

1. Gustaviani R. Diagnosis dan klasifikasi diabetes melitus. Dalam : Sudoyo AW, Setiyohadi B, Alwi I, Simadibrata M, Setiati S. Buku ajar ilmu penyakit dalam. Edisi IV. Jilid III. Jakarta : Pusat Penerbitan Departemen IImu Penyakit Dalam FKUI:1857-9 (2007).

2. Abbas AK, Maitra A. The endocrine system. In: Kumar V, Abbas AK, Nelson F. Robbins and Cotran. Pathologies basis of disease. 7th ed. Philadelphia, USA : Elsevier Saunders, h. 1155-224 (2005).

3. Lubis, I. Manifestasi Diabetes Melitus Dalam Rongga Mulut. Jakarta. (2012).

4. Sjamsuhidajat R, Wim de Jong. Buku Ajar IImu 
Bedah. Edisi 2. Jakarta: EGC, 67-8 (2004).

5. Langlais, R P, Miller, C S. Atlas Berwarna: Kelainan Rongga Mulut Yang Lazim. Cetakan I. Diterjemahkan oleh: Susetya Budi. Jakarta: Penerbit Hipokrates,h. $26,84(2000)$

6. Birnbaum, W dan Dunne, S M. Diagnosa Kelainan Dalam Mulut. Cetakan 2010. Diterjemahkan oleh: Ruslijanto Hartono, Rasyad M Enny. Jakarta. Buku Kedokteran EGC. h. 242-254 (2010).

7. Tanaka, A dkk. Histological Examination of the Distribution Change of Myofibroblast in Wound Contraction. Jepang: Emwa Journal: European Wound Management Association Vol. 4, No.1, h. 1314 (2004).

8. Balin AK, Pratt L. Dilute povidone-iodine solutions inhibit human skin fibroblast growth. Dermatol Surg. Mar; 28(3): 210-4 (2002).

9. Vogt PM. PVP-iodine in hydrosome and hydrogel- a novel concept in wound therapy leads to enhanced epiteliazation and reduced loss of skin grafts. Burn; 32(6): 698-705 (2006).

10. Paarakh, P. M. Nigella sativa Linn, A Comprehensive Review. Indian Journal of Natural Products and Resources, 1(4); 409-429 (2010)

11. Mayefis, D. Pengaruh Kombinasi Ekstrak Herba Papagan (Centella asiacita L.) dan Getah Pepaya (Carica papaya L.) terhadap Penyembuhan Luka Bakar Pada Mencit PutihJantan. Padang. (2011).

12. Gultom, O, Wardhani, SR, Evacuasiany, E. Pengaruh Getah Pepaya Terhadap Proses penyembuhan Luka Sayat Pada Mencit Galur Swiss Webster Betina. Jakarta.(2010).

13. Aswatan, G. Metodologi dan Aplikasi Penelitian Keperawatan. Jakarta: EGC. (2009).

14. Furnawathi I. Khasiat dan Manfaat Lidah Buaya Si Tanaman Ajaib. Edisi ke-7. Jakarta: Agromedia Pustaka. (2006).

15. Cole L, Heard C. Skin Permeation enchancment potential of Aloe vera and a proposed mechanism of action based upon size exlusion and pull effect. Intern J Pharmaceutics; 333:10-6 (2007).

16. Sulistiawati, IDAN. Pemberian Ekstrak Daun Lidah Buaya Konsentrasi 75\% Lebih Menurunkan Jumlah
Makrofag Daripada Konsentrasi 50\% dan 25\% Pada Radang Mukosa Mulut Tikus Putih Jantan. Denpasar. (2011).

17. Amirshahrokhi, A.R. Dehpour a, J. Hadjati b, M. Sotoudeh C, M. Ghazi-Khansari. Methadone ameliorates multiple-low-dose streptozotocininduced type. Diabetes 44:40 (2008).

18. Kusumawati, D. Bersahabat Dengan Hewan Coba. Yogyakarta: UGM Press (2004).

19. Pierce. Patofisiologi Konsep Klinik proses-proses penyakit. Edisi 6. Jakarta : EGC (2001).

20. Fitria, M. Saputra, D. Revilla, G. Pengaruh papain getah pepaya terhadap pembentukan jaringan granulasi pada penyembuhan luka bakar tikus percobaan. Jurnal FK UNAND. (2014).

21. Kim, Y S dkk. Therapeutic Effect of Total Ginseng Saponin on Skin Wound Healing. Korea: Journal of Ginseng Research, Vol.35, No.3, h.360-361 (2011).

22. Santi, M. Patofisiologi : Konsep klinis proses-proses penyakit. Edisi 6. Jakarta. Buku kedokteran EGC (2005).

23. Nopitasari, G. Pengetahuan Klinis praktisi. Edisi kedua. Jakarta. (2006).

24. Agrawal, S, Sharma, T R. Multiple Activities Of Aloe Barbadensis (Aloe Vera): An Overview. India: Asian Journal of Pharmacy \& Life Science Vol. 1, No. 2, h. 196-197 (2011).

25. Robbins, S L, Kumar, V, Cotran, R S. Buku Ajar Patologi I. Diterjemahkan Oleh: Prasetya Awal, Pendit B U, Priliono Toni. Jakarta: EGC, h. 52-78 (2007).

26. Hartawan, E K. Sejuta Khasiat Lidah Buaya. Jakarta: Penerbit Pustaka Diantara, h. 11-25 (2012).

27. MacKay, D and Miller, A L. Nutritional Supports for Wound Healing. Dover, Idaho: Alternative Medicine Review, Vol. 8, No. 4, h. 362 (2003). 